\title{
A Cross-Sectional Study of Electronic Media Influence on Eating Habits among School Going Adolescents
}

\author{
Salman Khalili1, Preeti Kumari², Farzana Alim³ ${ }^{3}$ Khursheed Muzammil ${ }^{4}$, \\ Syed Esam Mahmood ${ }^{5}$, Nazim Nasir 6 , Atiq Ul Hassan7, Izhar Hussain ${ }^{8}$
}

\begin{abstract}
${ }^{1}$ Department of Community Medicine, Jawaharlal Nehru Medical College, Aligarh Muslim University, Aligarh, Uttar Pradesh, India. 2, 3 Department of Home Science, Faculty of Agricultural Sciences, AMU Aligarh, Uttar Pradesh, India. ${ }^{4}$ Department of Public Health, College of Applied Medical Sciences, Khamis Mushayt Campus, King Khalid University, Abha, Kingdom of Saudi Arabia. ${ }^{5}$ Department of Family \& Community Medicine, College of Medicine King Khalid University, Abha, Kingdom of Saudi Arabia. 6,7 Department of Basic Sciences, College of Applied Medical Sciences, Khamis Mushayt Campus, King Khalid University, Abha, Kingdom of Saudi Arabia. ${ }^{8}$ Department of Management, Seacom Skills University, Kolkata, West Bengal, India.
\end{abstract}

\section{ABSTRACT}

\section{BACKGROUND}

Adolescence is the phase of transition when a child's body changes into that of an adult. Food product advertisements through electronic media may influence the eating habits amongst adolescents. The study aimed to find the usage of electronic media and its influence on the changing trends in the eating habits among adolescents.

\section{METHODS}

This is a school-based cross-sectional study conducted for three months in the three randomly selected schools of Ramghat Road locality of Aligarh City, U.P., India. A total of 600 adolescents formed the study sample selected by convenient sampling. A close-ended self-structured and pre-tested questionnaire was used as the study tool. Ethical clearance \& consent were obtained from the Principal of the respective schools \& study subjects. Data were entered in Microsoft Excel and analyzed by SPSS version 25 .

\section{RESULTS}

All adolescents had access to at least one form of electronic media. Television was the most preferred electronic medium (42.83\%). Majority of the television viewers (70.3 $\%$ ) watched TV for more than 2 hours a day. About $68.2 \%$ of adolescents were bodyconscious. About $66.5 \%$ were under the influence of advertisements for their eating habits. Around $48.8 \%$ of the subjects preferred junk foods. Among the television viewers, majority (93.8\%) had the habit of eating food items while watching television.

\section{CONCLUSIONS}

There is a statistically significant influence of electronic media in changing the eating habits of adolescents. It is recommended to have strict advertisement policy for food products being advertised, targeting adolescents as they have a direct or indirect effect on their health.

\section{KEY WORDS}

Electronic Media, Food Advertisements, Eating Habits, Adolescents
Corresponding Author: Salman Khalil. Department of Community Medicine, Jawaharlal Nehru Medical College, Aligarh Muslin University, Aligarh, Uttar Pradesh, India. E-mail: skhalilazmi@gmail.com

DOI: 10.14260/jemds/2020/756

How to Cite This Article:

Khalil S, Kumari P, Alim F, et al. A crosssectional study of electronic media influence on eating habits among school going adolescents. J Evolution Med Dent Sci 2020;9(46):3452-3456, $10.14260 /$ jemds/2020/756 DOI:

Submission 09-08-2020,

Peer Review 02-10-2020,

Acceptance 09-10-2020,

Published 16-11-2020.

Copyright (C) 2020 Salman Khalil et al. This is an open access article distributed under Creative Commons Attribution License [Attribution 4.0 International (CC BY 4.0)] 


\section{BACKGROUND}

Adolescence is the phase of transition when a child transforms into an adult. During this transformation physical, cognitive, and psycho-social changes are encountered in an adolescent. An adolescent has an increased nutritional requirement in the form of proximate principles and micronutrients. It has been observed that eating behaviours are variable among adolescents. Some adolescents opt dieting and thereby miss their meals leading to under nutrition while others indulge in overeating leading to obesity. Excess use of electronic media during leisure time, resulting in physical inactivity and not playing outdoor games or sports further contributes to these adverse dietary habits among adolescents. Thus electronic media plays a vital role in influencing the eating habits amongst these young adults.

A plethora of studies have reported that during excess electronic media usage especially television (TV) viewing among adolescents; there is an increase in the intake of food items like sugars, fast foods \& beverages and less likely to consume fruits and green leafy vegetables. ${ }^{1}$ The adoption of such unhealthy dietary behaviour can be attributed to the fact that they are consistently influenced by commercial food advertisements of energy-dense food items with deficient essential nutrients.

Electronic media uses electronics or electromechanical audience to access the content. Modern media is predominantly in the form of digital media. Any instrument or equipment used in the automated communication process (e.g. television, radio, mobile, computer, video game console, handheld devices, etc.) may also be considered electronic media. The use of electronic media has become an essential part of everyone's life, especially adolescents and schoolgoing children. It has become almost impossible nowadays to avoid the use of electronic media in his or her daily life with the ongoing technological advancement all over the world. The current media era has witnessed many changes, including a wide variety of information, communication and entertainment. In general, types of electronic media include television, smartphone, tablet and computer, both desktop and laptop. ${ }^{2}$

There are many advantages as well as disadvantages of the multiple types of electronic media. It may be a beneficial source of information and entertainment, but on the contrary, it may be addictive leading to health-related issues. ${ }^{3}$ Advertisements of food products on electronic media influence the food choices and preferences of the adolescents and motivate them to consume these advertised products. Adolescents using the different types of available electronic media devices may develop adverse eating behaviours influencing their health status. As per our knowledge, there is no similar study conducted previously in this region. With the above background, this cross-sectional study was undertaken to find out the influence of the usage of different electronic media devices on the eating habits of school-going adolescents. The objectives of this current study were set as to find out the type of electronic media device used by the adolescents, to determine the duration of the usage of different kind of electronic media devices and to assess the influence of electronic media devices on the eating habits among school-going adolescents in the study region.

\section{METHODS}

This three-month cross-sectional study was conducted in three selected schools out of six government schools of Ramghat Road locality of Aligarh City, U.P., India. To select schools as study setting, simple random sampling technique was used. A total of 100 male \& 100 female adolescents from each of these three schools were selected randomly as study subjects making a sample size of 600 study subjects ( 300 boys and 300 girls) by convenient sampling. All these randomly chosen study subjects were administered a closed-ended selfstructured and pre-tested questionnaire in their classroom as a study tool to record their responses to the study. A pilot study 60 study subjects (10\% of sample size) had also been undertaken before the start of the study, and necessary changes were made in the study tool where ever necessitated. Institutional Ethical Committee clearance was taken well in advance. Prior consent was also taken from the Principals of the respective schools and the study subjects. The confidentiality of the study subjects 'data collected was strictly maintained.

\section{Statistical Analysis}

Collected data were entered in Microsoft Excel and analyzed by SPSS 25.0 version. Chi-square test was used. A p-value of < 0.05 was considered significant.

\section{RESULTS}

\begin{tabular}{|c|c|c|c|c|c|c|}
\hline \multirow{2}{*}{ Traits } & \multicolumn{5}{|c|}{ Type of Preferred Electronic Media Usage by Gender } & \multirow{2}{*}{$\begin{array}{c}\text { P- } \\
\text { Value }\end{array}$} \\
\hline & & & & & & \\
\hline & $156(520)$ & & & & & \multirow{3}{*}{$\begin{array}{c}< \\
0.00001\end{array}$} \\
\hline & & & & & & \\
\hline Total & 243 & $66(1$ & $257(42.83)$ & 34 & & \\
\hline \multirow{2}{*}{ Traits } & \multicolumn{5}{|c|}{$\begin{array}{c}\text { Type of Preferred Electronic Media Usage by Age- } \\
\text { Group (Years) }\end{array}$} & \multirow{2}{*}{$\begin{array}{c}\text { p- } \\
\text { Value }\end{array}$} \\
\hline & Smartphone & Computer & Television & others & Total (600) & \\
\hline $10-13$ & & & & & & \\
\hline & & & & & & - \\
\hline $16-$ & 1 & & & & & 0.000 \\
\hline & $243(40.5)$ & 66( & 257 (42.8) & & & \\
\hline \multirow[t]{2}{*}{ Traits } & \multicolumn{5}{|c|}{$\begin{array}{c}\text { Usage duration of Preferred Electronic Media } \\
\text { (Hours) }\end{array}$} & \multirow[t]{2}{*}{$\begin{array}{c}\text { P- } \\
\text { Value }\end{array}$} \\
\hline & Smartphone & Computer & & & & \\
\hline & & & & & & \multirow{4}{*}{$\begin{array}{c}< \\
0.00001\end{array}$} \\
\hline & & & & & & \\
\hline & & & & & & \\
\hline Total & 10.5) & $66(11.0)$ & $257(42.8)$ & $34(5.7)$ & 60 & \\
\hline \multirow[b]{2}{*}{ Traits } & \multicolumn{5}{|c|}{ Type of Program Watched by Gender } & \multirow{2}{*}{$\begin{array}{c}\text { P- } \\
\text { Value }\end{array}$} \\
\hline & Spor & Rel & $\begin{array}{l}\text { Cookery } \\
\text { Show }\end{array}$ & Entertain- & To & \\
\hline Male & & & & & & \multirow{3}{*}{0.00001} \\
\hline Female & & & & & & \\
\hline Total & $147(24.5)$ & $91(15.2)$ & $99(16.5)$ & $263(43.8)$ & $600(1$ & \\
\hline \multirow[b]{2}{*}{ Traits } & \multicolumn{5}{|c|}{ Type of Program Watched by Age-Group } & \multirow{2}{*}{$\begin{array}{c}\text { P- } \\
\text { Value }\end{array}$} \\
\hline & Sports & Religiou & $\begin{array}{l}\text { Cookery } \\
\text { Show }\end{array}$ & $\begin{array}{l}\text { Entertain- } \\
\text { ment }\end{array}$ & Tot & \\
\hline $10-13$ & & & & & & \multirow{4}{*}{$\begin{array}{c}< \\
0.00001\end{array}$} \\
\hline & & & & & & \\
\hline $16-19$ & $87(36.9)$ & $48(2$ & $56(23.7)$ & 45 (19.1) & $236(100)$ & \\
\hline Total & $147(24.5)$ & $91(15.2)$ & $99(16.5)$ & $263(43.8)$ & $600(100)$ & \\
\hline \multicolumn{7}{|c|}{$\begin{array}{l}\text { Table 1. Distribution of Adolescents Using Electronic Media } \\
\text { According to Age and Gender }(N=600)\end{array}$} \\
\hline & & & & & & \\
\hline
\end{tabular}


Table 1 depicts that $100 \%$ of the study subjects have the accessibility of at least one form of electronic media. Television was the most preferred electronic media (42.83\%) accessible to them, followed by smartphone (40.5\%). Majority of the television viewers $(70.3 \%)$ watch television for more than 2 hours a day. Majority of the adolescents watch entertainment programs (43.8\%) followed by sports (24.5\%). All these findings have found to be statistically significant.

\begin{tabular}{|c|c|c|c|c|}
\hline \multirow[t]{2}{*}{ Traits } & \multicolumn{3}{|c|}{$\begin{array}{l}\text { Gender Wise Body Consciousness Development } \\
\text { from EM Usage }\end{array}$} & \multirow[t]{2}{*}{ P-Value } \\
\hline & Yes & No & Total (600) & \\
\hline \multirow{3}{*}{$\begin{array}{c}\text { Male } \\
\text { Female } \\
\text { Total }\end{array}$} & $201(67.0)$ & 99 (33.0) & $300(100)$ & \multirow{3}{*}{$>0.05$} \\
\hline & $208(69.3)$ & $92(30.7)$ & $300(100)$ & \\
\hline & $409(68.2)$ & $191(31.8)$ & $600(100)$ & \\
\hline \multirow[t]{2}{*}{ Traits } & \multicolumn{3}{|c|}{$\begin{array}{l}\text { Age-Group Wise Body Consciousness } \\
\text { Development from EM Usage }\end{array}$} & \multirow[t]{2}{*}{ P-Value } \\
\hline & YES & No & Total (600) & \\
\hline \multirow{3}{*}{$\begin{array}{l}10-13 \\
14-15 \\
16-19\end{array}$} & $122(72.6)$ & $46(27.4)$ & $168(100)$ & \multirow{4}{*}{$<0.05$} \\
\hline & $114(58.2)$ & $82(41.8)$ & $196(100)$ & \\
\hline & $173(73.3)$ & 63 (26.7) & $236(100)$ & \\
\hline Total & $409(68.2)$ & 191 (31.8) & $600(100)$ & \\
\hline \multicolumn{4}{|c|}{ Gender Wise Influence of Advertisement to Eating } & \multirow{3}{*}{ P-Value } \\
\hline \multirow[t]{2}{*}{ Traits } & \multicolumn{3}{|c|}{ Habits } & \\
\hline & YES & NO & Total (600) & \\
\hline Male & $196(65.3)$ & $104(34.7)$ & 30 & \multirow{3}{*}{$>0.05$} \\
\hline Female & 203 (67.7) & 97 (32.3) & $300(100)$ & \\
\hline Total & $399(66.5)$ & 201 (33.5) & $600(100)$ & \\
\hline \multirow{2}{*}{\multicolumn{4}{|c|}{$\begin{array}{l}\text { Age-Group Wise Influence of Advertisement to } \\
\text { Eating Habits }\end{array}$}} & \multirow{3}{*}{ P-Value } \\
\hline & & & & \\
\hline \multirow{4}{*}{$\begin{array}{l}10-13 \\
14-15 \\
16-19\end{array}$} & YES & No & Total (600) & \\
\hline & $118(70.2)$ & $50(29.8)$ & 168 & \multirow{4}{*}{$<0.05$} \\
\hline & $112(57.1)$ & 84 (42.9) & $196(100)$ & \\
\hline & 169 (71.6) & 67 (28.4) & $236(100)$ & \\
\hline Total & $399(66.5)$ & $201(33.5)$ & $600(100)$ & \\
\hline \multirow{3}{*}{ Traits } & \multirow{2}{*}{\multicolumn{3}{|c|}{$\begin{array}{c}\text { Gender Wise Tendency of Having Food Items after } \\
\text { Watching Such Advertisements on EM }\end{array}$}} & \multirow{3}{*}{ P-Value } \\
\hline & & & & \\
\hline & YES & No & Total (600) & \\
\hline Male & $154(51.3)$ & $146(48.7)$ & $300(100)$ & \multirow{3}{*}{$>0.05$} \\
\hline Female & $151(50.3)$ & $149(49.7)$ & $300(100)$ & \\
\hline Total & $305(50.8)$ & $295(49.2)$ & $600(100)$ & \\
\hline \multirow[t]{2}{*}{ Traits } & \multicolumn{3}{|c|}{$\begin{array}{l}\text { Age-Group Wise Tendency of Having Food Items } \\
\text { after Watching Such Advertisements on EM }\end{array}$} & \multirow[t]{2}{*}{ P-Value } \\
\hline & YES & NO & Total (600) & \\
\hline $10-13$ & $106(63.1)$ & $62(36.9)$ & $168(100)$ & \\
\hline $14-15$ & $58(29.6)$ & $138(70.4)$ & $196(100)$ & 00001 \\
\hline $16-19$ & 141 (59.7) & $95(40.3)$ & $236(100)$ & \\
\hline Total & $305(50.8)$ & 295 (49.2) & $600(100)$ & \\
\hline & $\begin{array}{r}\text { Table 2. Distrib } \\
\text { El }\end{array}$ & $\begin{array}{l}\text { Adolescent } \\
\text { c Media (EM }\end{array}$ & $\begin{array}{l}\text { ious Influences of } \\
\text { 00) }\end{array}$ & \\
\hline
\end{tabular}

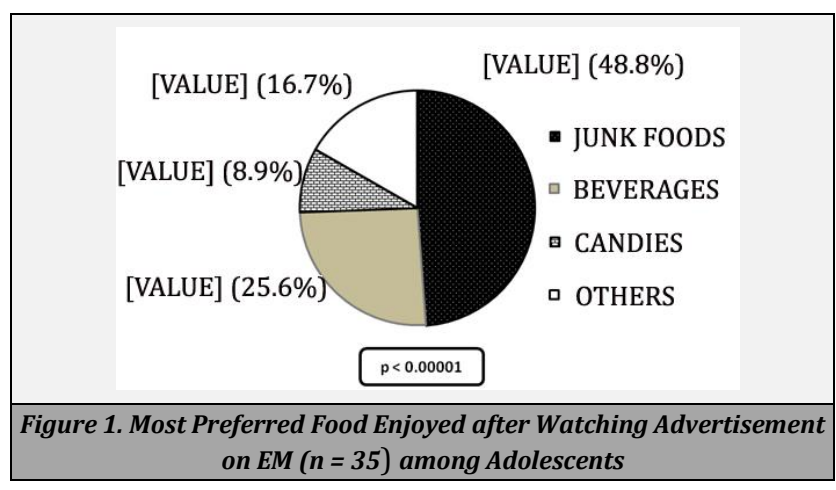

Table 2 revealed that $67 \%$ of males and $69.3 \%$ of female adolescents were body-conscious due to electronic media usage. About $66.5 \%$ of subjects were under the influence of electronic media advertisements on their eating habits. Nearly $50.8 \%$ have developed a tendency of eating food items after watching such promotional ads on electronic media. The gender differences in all of these three aspects were found to be insignificant. However, the differences between early, mid and late adolescents on all of these three aspects were found to be statistically significant.

Figure 1 depicts that $48.8 \%$ of the subjects have junk foods as their most preferred food product after watching advertisements on electronic media, followed by beverages $(25.6 \%)$. The difference between the eating preferences of the food products on this aspect was found to be significant.

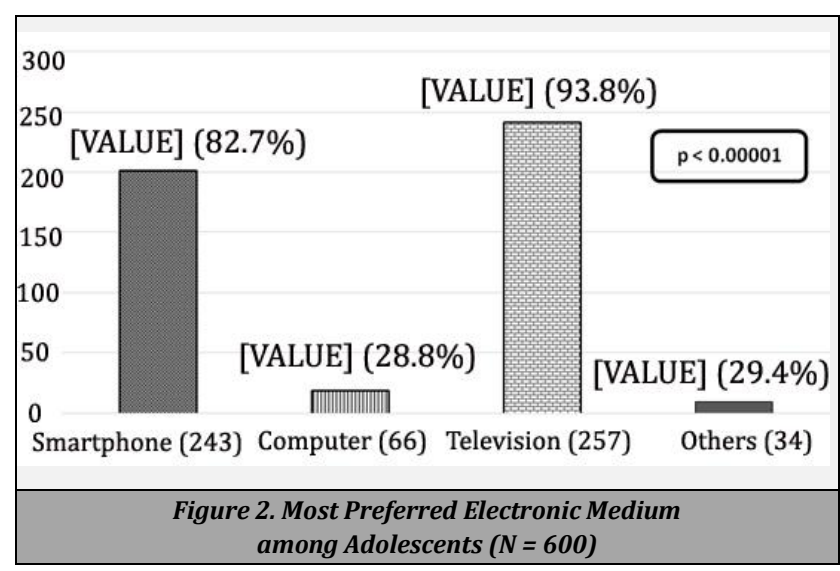

Figure 2 shows that out of 257 adolescents who have television as their preferred media to use, 241 (93.8\%) have the habit of eating while watching TV and out of 243 adolescents who have smartphones as their favourite media to use, $201(82.7 \%)$ have the habit of eating while using smartphones. This difference has also found to be statistically significant.

\section{DISCUSSION}

Adolescence is a critical period of change full of problems and is considered as a dreaded age, time of unrealism and threshold of adulthood. In this period, adolescents are confused as because they are in the transformation phase from childhood to adulthood. ${ }^{4}$ The use of electronic media has become a part of everyone's life, and adolescents are no longer spared about the advantages and disadvantages of electronic media especially television, mobiles and computers. ${ }^{2,3}$ Psychological pressures on adolescents influence their eating habits. Adolescents have increased nutrient needs, and, in this period, they may decide to start dieting or missing the meals. Peer pressure generally affects their eating pattern and result in either over or under eating. Adolescents develop a liking for fast foods which are nutritionally inadequate and rich in saturated fats, and they may skip meals at a time. Ideally, the adolescent should be educated to have a balanced diet and avoid junk foods providing empty calories; they should be advised not to miss the meals and that, emotions should not dominate during the mealtime. Teens spend more time outside with friends and less time with family. As they become more independent, their tendency to eating away from home increases.

The prevalence of snacking (defined as the consumption of foods and drinks between meals, including milk drinks, regular soft drinks, sports drinks and energy drinks) among adolescents and children varies widely across the world. For 
example, 87 - $88 \%$ of American adolescents (aged 12 - 18 years) consume at least one snack per day, with snacks contributing approximately $25 \%$ of their daily energy intake. 5

David et al. in their study revealed that adolescents have at least one form of modern media. He found the percentage of such adolescents to be $80 \%{ }^{6}$ However, the same was found to be $100 \%$ in the current study in the form of smartphones, computers, television and other gadgets / devices, and this was found to be statistically significant. (Table 1) In another research, it has been stated that the internet is used by adolescents as a mean of their communication. The use of the internet is fast and is reaching a more significant number of people all across the world. The internet is also used as a tool to make social relationships. ${ }^{7,8}$ In our study, the same is also consistent as all the adolescents are using some or other form of electronic media / devices viz., $40.5 \%, 11 \%, 42,83 \%$ \& $5.67 \%$ of the study subjects use smartphones, computers, television \& other gadgets respectively, and this was found to be statistically significant. (Table 1)

In another study, it was revealed that quite a lot of time is spent on computers by adolescents. Teenagers are sparing most of their time for computers in building social relationships and ties by way of social networking sites, internet, blogs, e-mails etc. which is similar to our finding as $70.3 \%$ of our study subjects spent $>2$ hours on TV daily, and this was found to be statistically significant. (Table 1) Bryant et al. in their study revealed that people spend about 2.2 hours a day on mobile phones by way of spending or receiving instant messages and remain in touch with peers or to make plans with them. ${ }^{9}$ In our study, the same has found to be in 14 $\%$ of subjects. (Table 1 )

Tosun et al. in their study argued that youngsters are more likely to adopt innovations and use latest technologies than adults. Most of the people are more or less dependent on the internet for information and entertainment purposes. ${ }^{10}$ In our study also similar finding has been reported as an entertainment program being watched by maximum (43.8\%) adolescents followed by sportive events $(24.5 \%)$, and this was found to be statistically significant. (Table 1)

Some studies stressed that different forms of media, especially television, convey messages to adolescents regarding the physical developments of the body and tend to play a role in developing a sense of body figure consciousness. ${ }^{8,11}$ In our study also, such consciousness has been noticed in adolescent males \& females to be $67 \%$ \& 69.3 $\%$ respectively; however, this was found to be statistically insignificant. (Table 2)

Healthy food habits are vital in an adolescent's life. Eating habits of children developed during childhood often change when they reach late adolescence because they enjoy more freedom and independence from parents. Davis has stated that proper nutrition plays an essential role as it is used to meet the adolescent's increased growth spurts. ${ }^{12}$ Khanna et al. in their study depicted that various factors influence the eating habits of adolescents. Adolescents lead a hectic lifestyle, \& they like to socialize more with their friends. They frequently neglect breakfast, and adolescent girls often skip lunch to reduce weight. Such kind of lifestyle creates a high impact on their eating habits. ${ }^{13}$ In a study, it has been stated that unhealthy eating habits can be a side effect of heavy or excessive media use. In a week, it was found that out of 10 adolescents one skips meals because they were busy watching television or playing video games. Every week, a quarter of the adolescents eat faster at least once to be able to view a programme or to play a computer game. Meal skipping occurred more frequently among respondents who were watching $>5$ hours of television daily. ${ }^{14}$

Many researchers, in general, have a uniform opinion that adolescents with heavy television viewing have an unhealthy lifestyle and easily get influenced by the food products advertised on television and pressurize their parents to buy those products \& tend to eat such foods more than other food. Robinson et al. in their study stated that watching TV has a direct impact on making choices regarding food, the reason for which could be exposed to unhealthy food advertisements. They revealed that heavy television viewers were prone to like \& consume food items advertised through TV. ${ }^{15}$ Surprisingly, these are almost similar to our results. (Table 2)

Since many years, children are consuming meals which are low in fruits and vegetables. Most of the time, they eat food rich in fat and sugar content. ${ }^{16-20}$ Lori et al. in their study found that children / youth while watching television tend to snack more which is low in nutrition. Exposure to such junk food advertised on television not only contributes to high-calorie levels but also causes many nutritional problems. ${ }^{21} \mathrm{~A}$ similar finding has also been revealed in the current study as $48.8 \%$ $\& 25.6 \%$ of the adolescents prefer junk foods and beverages respectively after watching advertisements on electronic media, and this difference has found to be statistically significant. (Figure 1) Out of 257 adolescents who have television as their preferred media to be used, 241 (93.8\%) have the habit of eating while watching TV, and out of 243 adolescents who have smartphones as their favourite media to be used, $201(82.7 \%)$ have the habit of eating while using smartphones. This difference has also found to be statistically significant. (Figure 2)

There is a relation between food products advertisements and food choices to be consumed. Most advertisements aimed at children and adolescents these days relates to fast foods, beating out even sweet and beverages. Food advertisements influence the food choices of children and adolescents. The messages for food advertisements on television especially are encouraging children and adolescents to view that what's good to eat is 'good for them'. Adolescents' use of electronic media can affect their food intake habits via two distinct pathways. First, the adolescent who is exposed to the steady stream of junk food advertisements may be vulnerable to enjoy food products rich in calories and low in nutrition. Second, adolescents who eat while watching television may be cued to eat (through the habit of commercial suggestion) and may consume more mindlessly than those who do not combine eating with viewing electronic media.

\section{CONCLUSIONS}

All the three age groups of adolescents, i.e., early, mid \& late adolescents irrespective of gender have access to all types of electronic media, and mostly being television followed by smartphones. Adolescents spend most of the time watching TV and playing or using smartphones. They use electronic media mainly for entertainment purposes. They like to eat junk foods followed by beverages under the influence of targeted food product's advertisements. There is a statistically significant 
influence of electronic media in changing the eating habits of adolescents.

There is a need to have strict advertisement policy for food products being advertised, targeting adolescents having a direct or indirect effect on their health in the long run. Enough emphasis should be given in the Education Policy regarding healthy food products to be consumed to remain healthy.

\section{Study Limitation}

Only three schools were selected for the study because of time constraints.

Data sharing statement provided by the authors is available with the full text of this article at jemds.com.

Financial or other competing interests: None.

Disclosure forms provided by the authors are available with the full text of this article at jemds.com.

Authors are thankful to AMU Aligarh, U.P., India and King Khalid University, Abha, KSA, for providing all the technical support and help. Authors thank all the principals, school teachers, study subjects and parents for their cooperation in this study.

\section{REFERENCES}

[1] Rey-López JP, Vicente-Rodríguez G, Répásy J, et al. Food \& drink intake during television viewing in adolescents: the healthy lifestyle in Europe by nutrition in adolescence (HELENA) study. Public Health Nutr 2011;14(9):1563-9.

[2] Yadhav KP. Encyclopedia of mass communication. Vol. 3. New Delhi: Sarup \& Sons 1998.

[3] Venkatesh V, Sykes TA, Chan FKY, et al. Children's internet addiction, family-to-work conflict and job outcomes: a study of parent-child dyads. MIS Quarterly 2019;43(3):903-27.

[4] Hurlock EB. Developmental psychology. $5^{\text {th }}$ edn. New Delhi: Tata McGraw-Hill Publishing Company 1981.

[5] Cross AT, Babicz D, Cushman LF. Snacking patterns among 1,800 adults \& children. J Am Diet Assoc 1994;94(12):1398-403.

[6] Ferdon CD, Hertz MF. Electronic media, violence and adolescents: an emerging public health problem. J Adolesc Health 2007;41(6 Suppl 1):S1-5.

[7] Gross EF, Juvonen J, Gable SL. Internet use and well being in adolescence. J Social Issues 2002;58(1):75-90.
[8] Ricciardelli LA, McCabe MP, Banfield S. Body image and body change methods in adolescent boys. Role of parents, friends and the media. J Psychosom Res 2000;49(3):18997.

[9] Bryant JA, Jackson AS, Smallwood AMK. et al. Iming, text messaging and adolescent social networks. J ComputerMediated Commun 2006;11(2):577-92.

[10] Tosun LP, Lajunen T. Why do young adults develop a passion for internet activities? The associations among personality, revealing "true self" on the internet and passion for the internet. Cyberpsychol Behav 2009;12(4):401-6.

[11] Morris AM, Katzman DK. The impact of the media on eating disorders in children \& adolescents. Paediatr Child Health 2003;8(5):287-9.

[12] John D. The impact of the mass media upon the health of early adolescents. J Health Educ 1993;24(Suppl 1):S2835.

[13] Khanna K, Gupta S, Passi SJ, et al. Textbook of Nutrition and dietetics. $2^{\text {nd }}$ edn. Elite Publishing 2016.

[14] Bulck JVD, Eggermont S. Media use as a reason for meal skipping and fast eating in secondary school children. J Hum Nutr Diet 2006;19(2):91-100.

[15] Robinson TN, Hammer LD, Killen JD, et al. Does television viewing increase obesity and reduce physical activity? Cross-sectional and longitudinal analyses among adolescent girls. Pediatr 1993;91(2):273-80.

[16] Fitzgibbon ML, Stolley M. Promoting health in an unhealthful environment: lifestyle challenges for children and adolescents. J Am Diet Assoc 2006;106(4):518-22.

[17] Robinson TN, Killen JD. Ethnic \& gender differences in the relationships between television viewing and obesity, physical activity and dietary fat intake. J Health Educ 1995;26(Sup 2):S91-8.

[18] Reger B, Wootan MG, Butterfield SB. Using mass media to promote healthy eating: a community-based demonstration project. Prev Med 1999;29(5):414-21.

[19] Höglund D, Samuelson G, Mark A. Food habits in Swedish adolescents in relation to socioeconomic conditions. Eur J Clin Nutr 1998;52(11):784-9.

[20] Lambert J, Agostoni C, Elmadfa I, et al. Dietary intake and nutritional status of children and adolescents in Europe. Br J Nutr 2004;92(Suppl 2):S147-211.

[21] Francis LA, Lee Y, Birch LL. Parental weight status and girls' television viewing, snacking and body mass indexes. Obes Res 2003;11(1):143-51. 